UDC 378:81-13+004.9

DOI https://doi.org/10.31470/2415-3729-2021-13-262-277

\title{
Current Educational Technologies in English Lexis and Grammar Distance Learning at General Secondary Education Institutions
}

\section{Nataliia Serdiuk}

Doctor of Philosophy in Pedagogy (Ph.D), Associate Professor, Associate Professor of the Department of Foreign

Philology, Translation and Methods of Teaching,

Pereiaslav-Khmelnytskyi Hryhorii Skovoroda State Pedagogical University,

Pereiaslav, Ukraine

$\triangle 30$, Sukhomlynsky Str., Pereiaslav, Ukraine, 08401

E-mail: serdiuk-n@ukr.net

ORCID: http://orcid.org/0000-0002-9865-6977

Date of receipt of the article: April 16, 2021 Article accepted for publication: June 02, 2021

\section{Сучасні освітні технології у дистанційному навчанні лексико- граматичного складу англійської мови у $33 \mathrm{CO}$}

\section{Наталія Юріївна Сердюк}

кандидат педагогічних наук, доцент, доцент кафедри іноземної

філології, перекладу та методики навчання, ДВНЗ «Переяслав-Хмельницький державний педагогічний університет імені Григорія Сковороди», м. Переяслав, Україна $\triangle$ вул. Сухомлинського, 30, м. Переяслав, Україна, 08401

Дата надходження статті: 16 квітня 2021 р. Стаття прийнята до друку: 02 червня 2021 р.

\section{Abstract}

The question of the specifics of modern distance learning remains one of the most pressing issues, especially in today's world affected by global virus pandemic. We consider the study of the use of modern educational 
technologies in English lexis and grammar distance learning relevant and timely. The purpose of the article is to characterize popular current educational technologies and their possibilities in distance learning of English lexical and grammatical structures, to define five most perspective online services for pupils of general secondary education institutions. Methods. The author implements the purpose with the help of theoretical (analysis and synthesis of own experience and of domestic scientists concerning the use of existing educational innovative computer technologies in English learning) and empirical research methods (observation of the educational process), together with the elements of statistical (analysis of student survey results). The results. Considering student survey results, the author's experience, the article names and characterizes 43 modern online educational technologies in English learning, they online platforms (Zoom, Microsoft Teams, Google Classroom, Skype, Nz.ua, ClassDojo, Moodl), online services (Google Drive, Padlet, Google Forms, Microsoft Forms, Kahoot!, Grammarly, Quizlet, Quizizz, Plickers, Socrative, Hot Potatoes, LinguaLeo, ToonDoo, Classtime, Lang-8, Coursera, LearnEnglish, BBC Learning English, British Council LearnEnglish, Tandem, Enpodcast, Bussu), mobile apps (Memrise, Rosetta Stone, Babbel, FluentU, MindSnacks, Open Language, Mosalingua, Messenger, Telegram, Viber, WhatsApp), virtual whiteboard (Paint, Google Slides, Bitpaper.io). The article suggests grouping these technologies according to 7 purposes of use (to conduct online English lessons in real time; to create virtual classes, lessons and tasks; to send tasks and communicate; online services for learning English vocabulary and grammar; to use a virtual board; to store works and materials of pupils; to assess and control English language skills). Conclusions. The benefit of the study is that the possibilities of online services in distance learning of English lexical and grammatical structures have been emphasized, and five the most perspective for pupils of general secondary education institutions have been defined as Moodle, Google Classroom, Google Forms, Kahoot!, Zoom.

Keywords: foreign language training, English distance learning, online services, online educational technologies, students survey.

\section{References}

1. Serdiuk, N. (2017). Modern trends in methods of foreign language training at the institutions of higher education in Ukraine. Theoretical and 
Didactic Philology, (26), 101-109. Retrieved from https://tdp-journal. com/index.php/journal/article/view/57

2. Serdiuk, N. \& Marchenko, N. (2016). Suchasni hadzhety v umovakh trylinhvalnoho navchannia maibutnikh uchyteliv inozemnykh mov [Modern gadgets in terms of trilingual education of future foreign language teachers]. Molodyi vchenyi - Young Scientist, (1), 535-539.

\section{Вступ}

Постановка проблеми. В умовах сьогодення, коли через пандемію COVID-19 мільйони дітей по всій країні мають виконувати свою шкільну роботу з дому, а класи стали віртуальними, питання специфіки сучасного навчання дистанційно залишається одним із найбільш актуальних питань. Особливо гостро воно постає у площині оволодіння знаннями та вміннями іноземних мов, оскільки для зростаючого покоління іншомовна компетенція $є$ однією з найцінніших i найкорисніших, адже може реалізовуватися в багатьох галузях i сферах життєдіяльності. На нашу думку, першочерговим для удосконалення навчання іноземних мов учнів загальної середньої та вищої освіти є оновлення методики шляхом імплементації новітніх засобів i інноваційних технологій, серед яких популярності набирають постійно діючі інтернет-сервіси, мобільні додатки тощо. Вважаємо дослідження питання використання сучасних освітніх технології у дистанційному навчанні лексико-граматичного складу англійської мови актуальним і своєчасним.

Аналіз актуальних наукових досліджень і публікацій. Проблему засвідчив, що різні аспекти цієї проблеми були предметом багатьох наукових розвідок, зокрема: дистанційне навчання іноземних мов - В. Гулак, Т. Мяновська, О. Олійник, С. Романюк та ін.; навчання іноземних мов в умовах карантину - С. Горбуньова, О. Кононенко, С. Сергіна, Н. Шалова та ін.; застосування технічних засобів і гаджетів у професійній іншомовній підготовці майбутніх учителів - М. Ілюшкіна, А. Лучко, Н. Сердюк, Н. Марченко та інші. Однак, недостатньо уваги приділяється застосуванню сучасних освітніх технологій у дистанційному навчанні лексико-граматичного складу англійської мови учнів базової школи.

На сьогодні методичне забезпечення викладання іноземних мов має бути розроблене на основі поєднання перспективних методів, 
підходів і відповідних інструментів для того, щоб заклади вищої освіти України могли успішно досягти своїх цілей стосовно формування іншомовної компетентності здобувачів певного рівня, навіть, в умовах загальнодержавного карантину. Звідси, підкреслюємо необхідність переважання сучасних методів і засобів у навчанні іноземних мов над традиційними і повне їх домінування під час дистанційного навчання.

Серед тенденцій у методиці навчання іноземних мов виявлено широке використання технічних засобів: комп'ютери, ноутбуки, портативні Bluetooth колонки та MP3 плеєри, персональні цифрові помічники (PDA), планшети, смартфони (Сердюк, Марченко, 2016; Serdiuk, 2017), айпади (iPad), айфони (iPhone), разом з різноманітними мобільними додатками та програмами, які уможливлюють швидкий і зручний доступ до всесвітньої павутини, що допомагає навчанню бути сучасним, цікавим, веселим, легким і більш ефективним.

Широкий ряд і функціональність таких інструментів підсилює потребу вивчення можливостей їх використання у навчанні, зокрема іноземних мов, тим паче тоді, коли залишається можливою лише віртуальна співпраця вчителя та учня, викладача та студента, як от в умовах пандемії, яка охопила безліч країн світу та позбавила нас найціннішого - спілкування тет-а-тет. Дякуючи зарубіжному досвіду та інноваціям, українська педагогічна спільнота має можливість ефективно впровадити різноманітні трендові онлайн-платформи, сервіси тощо, які стануть певними перспективними помічниками педагогам, в першу чергу для ефективного навчання іноземних мов, у тому числі лексико-граматичного складу англійської мови, учнівського колективу.

Аналіз вітчизняної та зарубіжної практики дозволив визначити існуючі сучасні онлайн-технології, які можуть стати в нагоді для удосконалення процесу навчання англійської мови перш за все під час дистанційного навчання, а також в умовах непередбачуваних надзвичайних ситуаціях типу карантину загальнодержавного рівня чи 3 інших поважних причин, або ж під час змішаного чи очного навчання, або ж, взагалі, задля потреб виховного процесу базової школи, наприклад проведення заходів онлайн.

Meта статmi - охарактеризувати популярні сучасні освітні технології та їх можливості у дистанційному навчанні лексико-гра- 
матичного складу англійської мови учнів базової школи, визначити 3 них найбільш перспективні.

\section{Матеріал і методи досліджень}

Матеріалом для дослідження слугували особисті спостереження, результати аналізу психолого-педагогічної літератури та студентського опитування.

Для досягнення мети використано такі методи:

- теоретичні: аналіз, синтез педагогічного досвіду власного та вітчизняних науковців стосовно використання існуючих освітніх інноваційних комп'ютерних технологій у навчанні англійської мови;

- емпіричні: спостереження за навчальним процесом;

- статистичні: аналіз результатів опитування студентів.

Учасниками опитування були 112 студентів факультету української та іноземної філології ДВНЗ «Переяслав-Хмельницький державний педагогічний університет імені Григорія Сковороди» (віком від 17 до 19, обох статей).

Опитування проводилося через Google форму і містило 3 блоки питань, які починалися такими основними 3 питаннями: «Чи відомі вам наступні платформи?», «Чи знаєте Ви як їх використовувати?», «Чи знаєте Ви як їх використовувати для навчання лексики та граматики англійської мови учнів базової школи?». Кожне з цих питань було головним у блоці та далі йшли певні назви платформ (Zoom, Microsoft Teams, Google Classroom, Skype, Nz.ua, ClassDojo, Moodle), сервісів (Google Drive, Padlet, Google Forms, Microsoft Forms, Kahoot!, Grammarly, Quizlet, Quizizz, Plickers, Socrative, Hot Potatoes, LinguaLeo, ToonDoo, Classtime, Lang-8, Coursera, LearnEnglish, BBC Learning English, British Council LearnEnglish, Tandem, Enpodcast, Bussu), мобільних додатків (Memrise, Rosetta Stone, Babbel, FluentU, MindSnacks, Open Language, Mosalingua, Messenger, Telegram, Viber, WhatsApp), віртуальних дошок (Paint, Google Slides, Bitpaper.io), загалом 43 одиниці. По кожній назві відповідного питання пропонувалися такі варіанти відповідей: «Так», «Посередньо», «Ні».

\section{Результати та їх обговорення}

Нами було визначено, що у середньому майже 90\% студентів знають 77\% названих у анкеті технологій, 82\% («гарно» та «посередньо») знають як користуватися 70\% із названих технологій, $78 \%$ знають як користуватися ними саме для навчання лексики та 
граматики англійської мови учнів базової школи, використовуючи загалом 65\% із названих технологій. Опитування студентів також засвідчило, що загалом для майбутніх учителів англійської мови $23 \%$ технологій є зовсім невідомими, навіть, за назвою, $30 \%$ із запропонованих технологій студенти не знають зовсім як загалом користуватися, $35 \%$ технологій є зовсім можливостей саме для навчання лексики та граматики англійської мови учнів базової школи. Опитування засвідчило, що необхідно знайомити студентів з існуючими сучасними освітніми технологіями та їх можливостями, зокрема для дистанційного навчання лексико-граматичного складу англійської мови у закладах середньої освіти.

На основі опитування студентів, дослідження трендових онлайнсервісів у формуванні іншомовної компетенції майбутніх вчителів іноземних мов і перекладачів (Сердюк, 2019), спробуємо охарактеризувати основні, на нашу думку, з сучасних онлайн-технологій, угрупувавши їх за певними аспектами, та визначити певні загальні особливості у формі відповідних, на нашу думку, плюсів («+») i мінусів («-»), а також можливості їх використання для вивчення лексико-граматичного складу англійської мови у 3ЗСО:

1. Для проведення онлайн-занять з англійської мови в реальному часі через відео-зв'язок використовуються такі популярні онлайнплатформи:

- Skype (www.skype.com) - кросплатформне програмне забезпечення для спілкування по всьому світу через відеозв'язок. Загальні особливості: 1) «+»- безкоштовне завантаження на будьякий пристрій (комп'ютер, ноутбук, планшет, Alexa, Xbox), наявність мобільного додатку; функція миттєвої зустрічі без реєстрації і завантаження (інтернет-версія); календар для заповнення учителем графіку занять; багаторазовий вхід за одним і тим самим посиланням-запрошенням учителя; безкоштовна участь 25 учасникам відеоконференції; не обмеженість у часі тривалості відео-зв'язку; наявні опції запису, демонстрації екрану, показу та завантаження матеріалів чи презентацій; наявність чату (приватний і груповий); можливість кожному учаснику виразити бажання взяти слово чи відповісти (іконка «піднята рука») та свої емоції («смайлики»); наявність платних тарифів 3 покращеними умовами (Skype Business); 2) «-» - обмежена кількість учасників безкоштовної відео-конференції (платно 
- від 25 до 50 осіб чи 250 (Skype Business)); необхідність спеціального Skype-номеру; одночасно на екрані може бути лише 10 відео-потоків; відсутність віртуального класу; можливі збої чи проблеми зображення або звуку; відсутність опції віртуальної дошки.

Можливості використання для вивчення лексики та граматики англійської мови у базовій школі: перехід на інтерфейс англійською (iз 38 можливих мов платформи) - для оволодіння новою лексикою (наприклад, для 8-9 класу, а для 5-7 класів - україномовний); показ матеріалу, презентації, відео - для вивчення нових слів, фраз, граматичних правил англійської мови та закріплення вже відомих; перехід на необхідну інтернет-сторінку, де пояснюється нове слово, фраза, граматична конструкція тощо - для наочності; чат - для виконання вправ і завдань, словникового диктанту, «мозкового штурму», опитування/квізу (для одночасності учні можуть, написавши відповідь, відправити цей коментар лише за командою вчителя - відповіді швидко за секунду-дві висвітлюються на екрані, як краплинки дощу, так званий метод «чат-дощу»); демонстрація виконаних завдань, написаного тексту, твору англійською мовою з подальшим аналізом тощо; завантаження у чат картинок, карток, зображень - для різноманітних ігор і вправ.

- Zoom (www.zoom.us) - платформа для спілкування по всьому світу у вигляді онлайн-зустрічей, -конференцій, -занять, -заходів через відеозв'язок. Загальні особливості: 1) «+» - безкоштовне завантаження на будь-який пристрій; наявність мобільного додатку; функція миттєвої наради без реєстрації і завантаження (в браузері); календар для планування онлайн-зустрічей через ПК, мобільний додаток, веб-портал, «Google Календар» чи Outlook тощо; можливість повторної конференції за однаковим ідентифікатором чи посиланням, багаторазовий вхід за посиланням; перший відеозв'язок не має обмежень ані в кількості учасників, ані в часі; наявні опції запису, чату, демонстрації екрану та завантаження матеріалів чи презентацій; наявність іконок («піднята рука», «смайлики»), різноманітних веселих масок, стікерів і фільтрів; наявність опції віртуальної дошки; наявність функції Immersive View, яка дозволяє віртуально поєднати до 25 учасників у одній віртуальній кімнаті (виглядає як реальний клас); наявність платних тарифів з покращеними умовами; не потрібно спеціального номеру (як у Skype); тривалість відео-зв'язку 
не обмежена часом, якщо є лише 2 учасники (учитель-учень); 2) «-» - якщо учасників троє і більше, то надається лише 40 хвилин (у платних тарифах необмежена тривалість конференцій, максимальна кількість 500 осіб; сплата одноразово за рік); обмежена кількість учасників безкоштовної відео-конференції (до 100 осіб); відсутність віртуального класу; можливі проблеми зображення або звуку через вади інтернету.

Можливості використання для вивчення лексики та граматики англійської мови майже такі самі, як у Skype, але перевагами $\epsilon$ функція поділу вчителем учасників на окремі групи («сесійні зали») для групової чи парної роботи на заняттях 3 англійської мови (для виконання комунікативних вправ, створювання діалогів за темою та проектів під час занять, проведення змагань, конкурсів або гри між командами) та відвідування кожної «зали», зміни учасників місцями (для контролю тощо); можливість вимкнути мікрофон будь-якому учаснику, усім чи частині, що унеможливлює підказки учням від однокласників, що може бути корисним під час опитування, розвитку монологічного та діалогічного мовлення; опція віртуального фону, де можна ставити будь-які картинки, фото (наприклад, для опису чи вгадування віртуального місцезнаходження вчителя, країни/міста/ будівлі/тощо, проведення віртуальної екскурсії, квесту і т.п. - сприятиме розвитку лексичного запасу, комунікативних вмінь, закріпленню лексико-граматичних конструкцій тощо); можливість зробити навчання у формі цікавої гри через віртуальну зміну зовнішнього вигляду учасників («надягання» веселих масок, фільтрів тощо); функція олівця/гумки віртуальної дошки може бути використана для малювання як учителем і учнем окремо, так і обома разом, наприклад, для графічного зображення граматичної конструкції чи певної схеми (для перевірки знань), написання слова, фрази, речення (для практики писемного мовлення, словникового диктанту, перекладу 3 української на англійську та навпаки тощо).

- Microsoft Teams (www.microsoft.com/en-ww/microsoftteams) - складова ліцензійної платформи Microsoft Office 365, що уможливлює ефективну співпрацю вчителя і учнів через онлайнзустрічі (аудіо- або відео-), роботу з документами тощо. Загальні особливості: 1) «+»- завантаження на будь-який пристрій; наявність мобільного додатку; календар для планування зустрічей (уроків/за- 
нять); створення каналу (тобто віртуального класу) з певного предмету; конференції завжди проводяться лише у створеному каналі (учень легко знаходить їх), можливість повторного приєднання до конференції; відеозв'язок не має обмежень ані в кількості учасників, ані в часі; наявні опції запису, текстового та голосового чату, віртуальної дошки, демонстрації екрану та завантаження матеріалів чи презентацій; наявність іконок («піднята рука», «смайлики»); учасниками можуть бути лише зареєстровані адміністратором особи (це унеможливлює вхід сторонніх осіб); можливість працювати 3 програмою, навіть, без інтернет-зв'язку, автоматична синхронізація; 2) «-»- відсутні функція миттєвої наради без реєстрації і завантаження та опція масок, стікерів і фільтрів; можливі проблеми зображення або звуку через вади інтернету.

Можливості використання Microsoft Teams для вивчення англійської мови приблизні, як у двох попередніх, але перевагами $є$ інструментарій для спільного перегляду, запису аудіо/відео, додавання субтитрів, перекладу аудіо і відео контенту, створення відеороликів; спільної роботи над документом; паралельний доступ до інших складових платформи Microsoft Office 365 (OneDrive, Microsoft Forms, Sharepoint, Outlook тощо) - для надсилання та збереження файлів, для комунікації з учнями, для проведення опитувань, тестувань, тощо; можливість вимкнути/увімкнути мікрофон певному учаснику(-кам) - для проведення квізу, «мозкового штурму», розвитку монологічного та діалогічного усного мовлення тощо.

Зазначимо, що дещо менше за частотністю користуються такою платформою як Duolingo for Schools, сервісами sAKAI, Webroom тощо.

2. Для створення віртуальних класів, уроків i завдань популярністю користуються платформи:

- Google Classroom (www.classroom.google.com) - безкоштовна платформа від компанії Google. Загальні особливості: 1) «+» - завантаження на будь-який пристрій; наявність мобільного додатку; календар заходів і занять; виконання учнями завдання лише у створеному класі; постійний доступ до створених учителем завдань, завантажених матеріалів чи презентацій, інтернет-посилань тощо; наявна опція чату; можливість повторного виконання завдання; створення віртуального класу з певного предмету лише через 
акаунт Google (це унеможливлює вхід сторонніх осіб); функція журналу; опція дедлайну до кожного завдання та нагадування на е-пошту; має доступ до інших сервісів і додатків Google; архів завдань; автоматичне завантаження завдань/матеріалів на Google Диск (і можливість завантажувати чи поширювати інформацію 3 нього); 2) «-» - відсутні функції відеозв’язку, віртуальної дошки, запису тощо.

- Nz.ua (www.nz.ua), яка має всі вище перераховані переваги (окрім прив'язки до акаунта та сервісів Google), а також інші: опція доступу батькам, наявність старости класу, персональних даних (наприклад, про Дні народження тощо); опція новин, статусу, спільнот; функції додаткової статистики та вибірки тощо.

- ClassDojo (www.classdojo.com), до якої теж можуть доступ батьки учнів;

- Moodle (www.moodle.org.), яка за основними особливостями (календар; віртуальний клас; постійний доступ до матеріалів дисципліни/курсу, програм і тестів тощо; чат; тощо) є дещо схожою 3 Google Classroom, але головною відмінністю $є$ те, що впровадження Moodle можливе лише на серверах закладу, що не можуть собі дозволити переважна частина 33СО. Тому частіше така ефективна платформа наявна у ЗВО.

3. Для надсилання завдань і спілкування можна використовувати всім відомі мобільні додатки як Messenger, Telegram, Viber, WhatsApp, але варто згадати і додатки, які створені для навчання саме англійської мови, типу:

- Memrise - безкоштовний додаток, який заснований на інтервальному методі повторення інформації через зорову пам'ять і передбачає запам'ятовування 44 слів на годину, шляхом автоматичного нагадування слів саме тоді, коли ви починаєте їх забувати; містить тисячі відео- й аудіозаписів, для вивчення слів, за 13 курсами від простої до складної тематики (наприклад, від English Irregular Verbs до складних слів з оригінального художнього твору);

- Rosetta Stone - платний додаток (безкоштовна демо-версія), який заснований на поступовому вивченні лексико-граматичних конструкцій шляхом вивчення слів, а потім складання з них речень без використання рідної мови для перекладу тощо, тобто навчання англійської англійською мовою. 
Опитування студентів засвідчило, що вони посередньо знають або зовсім не знають такі додатки як Babbel, FluentU, MindSnacks, Open Language, Mosalingua, які теж можуть використовуватися у базовій школі для самостійної роботи, наприклад.

4. Онлайн-сервіси для навчання англійської лексики та граматики:

- Hot Potatoes (www.hotpot.uvic.ca) - безкоштовний і простий у користування сервіс створення завдань закритого типу (множинний вибір, пошук відповідників, заповнення пропусків), який допоможе вивчити лексичний чи граматичний матеріал будь-якого рівня складності;

- LinguaLeo (www.lingualeo.com)- безкоштовний популярний сервіс, який забезпечує вивчення нових слів і фраз, удосконалення правопису, надає доступ, навіть, до офлайн словника, великої кількості медіаресурсів, прослуховування англомовного озвучування текстів, перекладу текстів пісень, дає можливість створення власного словника; де цікавою фішкою є гейміфікація додатку (тобто перехід на наступний рівень у формі гри, типу потрібно заробити певні бонуси/виконати завдання, які допоможуть перескочити вище); існує платна версія з преміум-пакетом функцій;

- ToonDoo (www.toondoo.com) - безкоштовний онлайн-сервіс для створення коміксів (наприклад, який може бути використаний для тренування умінь вживання відповідних лексичних одиниць при вирішенні комунікативного завдання);

- Classtime (www.classtime.com) - онлайн-сервіс для створення миттєвої візуалізації рівня розуміння та прогресу учнів; може використовуватися як онлайн, так і оффлайн.

- Bussu (www.busuu.com) - платний сервіс вивчення мов (11 мов світу) за різними курсами, які розділені за складністю та містять різноманітні завдання на читання, аудіювання, написання міні-твору за обраною тематикою, які перевірятимуть носії мови; перевага над іншими - спілкування з носіями.

Посередньо відомими та зовсім не відомими для студентів переважно виявилися такі перспективні та цікаві, на нашу думку, сервіси, як: ВВС Learning English, British Council Learn English, Coursera, Engvid, Enpodcast, ExamEnglish, FreeRice, Lang-8, LearnEnglish, Livemocha, Myspelling, Tandem, TED, ManyThings. 
5. Для використання віртуальної дошки під час уроку можна використовувати: Paint, Google Slides, Bitpaper.io та інші.

6. Для зберігання робіт і матеріалів кожного учня - всім відомий Google Drive та менш відомий студентам Padlet (www.padlet.com), що представляє собою зручний онлайн-сервіс для збереження, організації та спільної віртуальної роботи віртуально. Можна застосовувати їх для «мозкового штурму», на етапі узагальнення та систематизації знань; як майданчик для розміщення навчальної інформації; для спільного або індивідуального виконання домашнього завдання; як місце для збирання ідей для проектів та їх обговорення.

7. Для оцінювання та контролю знань англійської мови використовуються:

- Google Forms (www.docs.google.com/forms) - безкоштовна можливість створення і використання опитувальників, вікторин, контрольних чи підсумкових завдань, тестів, у тому числі множинного вибору, завдань для самостійної перевірки знань, які уможливлюють перевірку знань певної теми, курсу чи англійської (або іншої) мови взагалі; інтерфейси є різними мовами.

- Microsoft Forms (www.office.com/launch/forms), подібні до вище названих.

- Kahoot! (www.kahoot.com) - безкоштовний онлайн-сервіс, який дає можливість створення і використання інтерактивних навчальних ігор опитувальників, вікторин, контрольних чи підсумкових завдань, тестів, у тому числі множинного вибору, завдань для самостійної перевірки знань, які уможливлюють перевірку знань певної теми, курсу чи англійської (або іншої) мови взагалі; інтерфейс англійською.

- Grammarly (www.grammarly.com/) - безкоштовна можливість для перевірки викладачами англомовного тексту, написаного студентом, на правильність граматики та пунктуації (а також відсутність плагіату), застосування такого інструменту під час навчальних занять для розвитку та перевірки умінь і навичок письмового мовлення, а також для самостійної перевірки студентами власних навичок письма; інтерфейс англійською.

- Quizlet (www.quizlet.com) - безкоштовний онлайн-сервіс для створення та застосування флеш-карток (режим «Cards») та навчальних ігор у різних категоріях, («Speller», «Learn», «Test», «Scatter», 
«Race»); інтерфейс англійською. ігор для тестування (обрати режим «Test» серед інших категорій «Speller», «Learn», «Scatter», «Race»); інтерфейс англійською.

- Quizizz (www.quizizz.com) - безкоштовна можливість для створення тестів, квізів, вікторин, опитувальників, контрольних чи підсумкових завдань у навчальному процесі, а також для самостійної перевірки студентами знань теми, курсу тощо; інтерфейс англійською.

- Plickers (www.plickers.com) - безкоштовний онлайн-сервіс, що дозволяє швидко проводити мобільні голосування і фронтальні опитування під час навчального заняття з вивченого або поточного матеріалу в тестовій формі, де результати миттєво виводяться на екран комп'ютера (телевізора, проектора), під’єднаного до Інтернету ; інтерфейс англійською.

Існує ще не надто затребувана на сьогодні, але теж перспективна платформа Socrative (www.socrative.com).

Аналіз теорії та практики підготовки студентів-філологів дозволив визначити перелік із 5 найбільш популярних і перспективних онлайн-сервісів, які удосконалюють навчання іноземних мов в умовах карантину 3CO, а саме: Moodle, Google Classroom, Google Forms, Kahoot!, Zoom.

\section{Висновки}

Опитування засвідчило, що третина запропонованих у анкеті онлайн-технологій $є$ невідомою для студентів, що актуалізує необхідність знайомити їх 3 існуючими сучасними освітніми технологіями та їх можливостями, зокрема для дистанційного навчання англійської мови у середній освіті. Таким чином, нами визначено та охарактеризовано сучасні освітні технології (онлайн-пратформи, сервіси, мобільні додатки тощо) та їх можливості для дистанційного навчання лексико-граматичного складу англійської мови. Також нами визначено перелік із 5 наразі найбільш, на нашу думку, популярних і перспективних онлайнсервісів для удосконалення навчання англійської мови в умовах дистанційного навчання, а саме: Moodle, Google Classroom, Google Forms, Kahoot!, Zoom.

Перспективою подальших досліджень $є$ детальне вивчення переваг і недоліків зазначених сервісів для формування іншомовної компетентності майбутніх вчителів іноземних мов. 


\section{Література}

3. Serdiuk, N. (2017). Modern trends in methods of foreign language training at the institutions of higher education in Ukraine. Theoretical and Didactic Philology, (26), 101-109. Retrieved from https://tdp-journal. com/index.php/journal/article/view/57

4. Сердюк, Н. Ю., \& Марченко, Н. М. (2016). Сучасні гаджети в умовах трилінгвального навчання майбутніх учителів іноземних мов. Молодий вчений, (1), 535-539.

\section{Сердюк Н.Ю.}

\section{Сучасні освітні технології у дистанційному навчанні лексико- граматичного складу англійської мови у $33 \mathrm{CO}$}

\section{Анотація}

Питання специфіки сучасного дистанційного навчання залишається однією 3 найактуальніших проблем, особливо в сучасному світі, на який впливає глобальна вірусна пандемія. Ми вважаємо вивчення використання сучасних освітніх технологій у дистанційному навчанні лексики та граматики англійської мови актуальним і своєчасним. Мета статті - охарактеризувати популярні сучасні освітні технології та їх можливості у дистанційному навчанні лексико-граматичного складу англійської мови учнів базової школи, визначити з них найбільш перспективні.

Методи. Автор для досягнення мети використав такі методи: теоретичні (аналіз, синтез педагогічного досвіду власного та вітчизняних науковців стосовно використання існуючих освітніх інноваційних комп'ютерних технологій у навчанні англійської мови); емпіричний (спостереження за навчальним процесом); елементи статистики (аналіз результатів опитування студентів).

Результати. Враховуючи результати опитування студентів, досвід автора, стаття називає та характеризує 43 сучасні освітні онлайн технології вивчення англійської мови, зокрема платформи (Zoom, Microsoft Teams, Google Classroom, Skype, Nz.ua, ClassDojo, Moodl), сервіси (Drive, Padlet, Google Forms, Microsoft Forms, Kahoot!, Grammarly, Quizlet, Quizizz, Plickers, Socrative, Hot Potatoes, LinguaLeo, ToonDoo, Classtime, Lang-8, Coursera, LearnEnglish, BBC 
Learning English, British Council LearnEnglish, Tandem, Enpodcast, Bussu), мобільні програми (Memrise, Rosetta Stone, Babbel, FluentU, MindSnacks, Open Language, Mosalingua, Messenger, Telegram, Viber, WhatsArp), віртуальну дошку (Paint, Google Slides, Bitpaper.io). У статті пропонується згрупувати ці технології відповідно до 7 цілей використання (проводити онлайн-уроки англійської мови в режимі реального часу; створювати віртуальні класи, уроки та завдання; надсилати завдання та спілкуватися; онлайн-сервіси для вивчення словникового запасу та граматики англійської мови; використовувати віртуальну дошку; зберігати твори та матеріали учнів; оцінювати та контролювати знання англійської мови).

Висновки. Перевага дослідження полягає в тому, що наголошено на можливості онлайн-технологій для дистанційного навчання лексико-граматичного складу англійської мови. Визначено перелік із 5 найбільш популярних і перспективних онлайн-сервісів для удосконалення навчання англійської мови в умовах дистанційного навчання, а саме: Moodle, Google Classroom, Google Forms, Kahoot!, Zoom.

Ключові слова: навчання іноземним мовам, дистанційне навчання англійській мові, онлайн-сервіс, освітні онлайн-технології, опитування студентів.

\section{Сердюк Н.Ю.}

\section{Сучасні освітні технології у дистанційному навчанні лексико- граматичного складу англійської мови у 33 СО}

\section{Аннотация}

Вопросы специфики современного дистанционного обучения остаются одной из самых актуальных проблем, особенно в современном мире, на который влияет глобальная вирусная пандемия. Мы считаем изучение использования современных образовательных технологий в дистанционном обучении лексики и грамматики английского языка актуальным и своевременным. Цель статьи - охарактеризовать популярные современные образовательные технологии и их возможности в дистанционном обучении лексико-грамматического состава английского языка учащихся базовой школы, определить из них самые перспективные. 
Методы. Автор для достижения цели использовал следующие методы: теоретические (анализ, синтез педагогического опыта собственного и отечественных ученых по использованию существующих образовательных инновационных компьютерных технологий в обучении английскому языку) эмпирический (наблюдение за учебным процессом), элементы статистики (анализ результатов опроса студентов).

Результаты. Учитывая результаты опроса студентов, опыт автора, статья называет и характеризует 43 современные образовательные онлайн технологии изучения английского языка, в частности платформы (Zoom, Microsoft Teams, Google Classroom, Skype, Nz.ua, ClassDojo, Moodl), сервисы (Drive, Padlet, Google Forms, Microsoft Forms, Kahoot !, Grammarly, Quizlet, Quizizz, Plickers, Socrative, Hot Potatoes, LinguaLeo, ToonDoo, Classtime, Lang-8, Coursera, LearnEnglish, BBC Learning English, British Council LearnEnglish, Tandem, Enpodcast, Bussu), мобильные приложения (Memrise, Rosetta Stone, Babbel, FluentU, MindSnacks, Open Language, Mosalingua, Messenger, Telegram, Viber, WhatsArp), виртуальная доску (Paint, Google Slides, Bitpaper.io). В статье предлагается сгруппировать эти технологии в соответствии с 7 целями использования (проводить онлайн-уроки английского языка в режиме реального времени создавать виртуальные классы, уроки и задачи; отправлять задания и общаться; онлайн-сервисы для изучения словарного запаса и грамматики английского языка, использовать виртуальную доску; хранить произведения и материалы учащихся; оценивать и контролировать знания английского языка).

Выводы. Преимущество исследования заключается в том, что отмечено возможности онлайн-технологий для дистанционного обучения лексико-грамматического состава английского языка. Определен перечень из 5 наиболее популярных и перспективных онлайнсервисов для усовершенствования обучения английскому языку в условиях дистанционного обучения: Moodle, Google Classroom, Google Forms, Kahoot!, Zoom.

Ключевые слова: обучение иностранным языкам, дистанционное обучение английскому языку, онлайн-сервис, образовательные онлайн-технологии, опрос студентов. 